DOI

\title{
МУЗЕЕФИКАЦИЯ ИСТОРИИ ЛАГЕРНЫХ КОНСТРУКТОРСКИХ БЮРО В ПЕРМИ
}

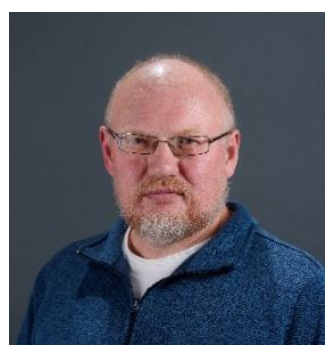

С.А. Шевырин,

канд. ист. наук, заведующий научно-методическим отделом, Мемориальный музей-заповедник «Пермь-36», Пермь shewirin@mail.ru

Аннотация. В годы Великой Отечественной войны на территории города Молотов (Пермь) были размещены эвакуированные исследовательские бюро - конструкторское и техническое при НКВД. Эти бюро состояли из заключенных-ученых, осужденных по сфабрикованным делам «во вредительстве», «шпионаже» и др. Ученых разместили при военных производствах города - пушечном и пороховом. Всю войну ученые изобретали новые системы вооружения, пороха, тем самым приближая Победу. В послевоенное время их деятельность и вклад в Победу были засекречены. Только на рубеже 1990-х - 2000-х годов эта страница истории стала доступна исследователям и началась работа по музеефикации памяти об этих людях и их деятельности.

Ключевые слова: ГУЛАГ, «шарашки», артиллерия, порох, НКВД, 58 статья, особое конструкторское бюро.

\section{MUSEUM OF THE HISTORY OF THE CAMP DESIGN BUREAUS IN PERM}

Sergey A. Shevyrin, Ph. D., Head of the Scientific and Methodological Department, Memorial Museum-Reserve «Perm-36», Perm shewirin@mail.ru 
Abstract. During the Great Patriotic War, the evacuated research bureaus - the design and technical offices of the NKVD-were located on the territory of the city of Molotov (Perm). These bureaus consisted of prisonersscientists convicted of fabricated cases of "sabotage", "espionage", etc. Scientists were placed at the military production facilities of the city - cannon and gunpowder. Throughout the war, scientists invented new weapons systems, gunpowder, thereby bringing Victory closer. In the post-war period, their activities and contribution to the Victory were classified. Only at the turn of the 1990s-2000s, this page of history became available to researchers and work began on museumification of the memory of these people and their activities.

Keywords: GULAG, "sharashki", artillery, gunpowder, NKVD, article 58, special design bureau.

На рубеже 1930-х гг. в советской пенитенциарной системе появились новые учреждения - конструкторские и технические бюро, в которых работали осужденные в большинстве своем по 58-й статье заключенные. Этому способствовало то, что в стране шла настоящая травля специалистов. Так, в результате «Шахтинского дела» 1928 г. десятки специалистов - инженеры, механики, техники - были обвинены в создании контрреволюционной вредительской организации и осуждены. После слов Сталина на апрельском пленуме 1929 г. - «Шахтинцы сидят теперь во всех отраслях нашей промышленности» - по всей стране начались поиски вредителей среди интеллигенции. Так, только за 1931 г. ОГПУ было осуждено 1152 инженера за «вредительство» [1, с. 102].

Наполнение лагерей и тюрем инженерами, техниками, химиками и т.д., естественно, вело к их значительной убыли на воле и привлечению внимания к этой особой группе заключенных высокого начальства. 15 мая 1930 г. появился особый циркуляр, подписанный председателем ОГПУ Г. Ягодой и председателем ВСНХ (Высший Совет народного хозяйства) В. Куйбышевым, который предлагал «...использовать вредителей ...таким образом, чтобы работа их проходила главным образом в помещении органов ОГПУ. ...Оказывать им содействие в деле постановки опытных работ...» [2, с. 46]. Но фактически к этому времени первое тюремное конструкторское бюро уже существовало. Попавших в разряд «вредителей» специалистов по самолетостроению и авиадвигателям ОГПУ сосредоточило в Бутырской тюрьме, где они еще в декабре 1929 г. занимались конструированием новых самолетов 
[3, с. 584]. После репрессий среди научно-технических работников на железной дороге ОГПУ при Транспортном отделе Народного комиссариата путей сообщения СССР было организовано Особое техническое бюро (ОТБ), в котором работали только что осужденные инженеры и конструкторы [4].

Циркуляр от 15 мая 1930 г. давал возможность широко распространить опыт Бутырской тюрьмы. Причем инженеров«вредителей» предполагалось использовать исключительно в области «производства новых средств вооружения армии и флота» [3, с. 444]. Такие тюремные КБ были организованы в Москве, Ленинграде, Таганроге, Ростове, Казани и других городах.

В Перми до 1941 г. таких КБ не было. В годы Великой Отечественной войны в Пермь (Молотов) были эвакуированы два тюремных бюро. Из-под Москвы (Болшево) было эвакуировано Особое техническое бюро (ОТБ) НКВД при Научно-исследовательском институте промышленности боеприпасов, а из ленинградских «Крестов» - артиллерийское Особое конструкторское бюро (ОКБ) № 172. Всю войну ученые-химики и конструкторы-артиллеристы изобретали и создавали новые пороха, пушки. В декабре 1944 г. ОКБ-172 возвратили в Ленинград, разместили в старых корпусах «Крестов». Большинство заключенных-химиков были освобождены в 1943 г.

Заключенные ОТБ при пороховом заводе А.С. Бакаев и Д.И. Гальперин в годы войны сумели найти замену редкому централиту (входил в состав зарядов «Катюши») и создали новый улучшенный состав баллиститного пороха. Разработанная этим же ОТБ система непрерывного шнекового производства ракетных зарядов увеличила в два раза скорость их изготовления [5, с. 13-14]. Именно это дало возможность гвардейскому реактивному миномету БМ-13 («Катюша») стать символом мощи советского оружия. Благодаря ученым-химикам из ОТБ НКВД Кировский завод в годы войны стал основным поставщиком порохов в стране [6, с. 20]. На счету лагерной «шарашки» ОКБ-172 - разработка пехотной противотанковой пушки М-42 («Аннушки»), модернизация 152-миллиметровой гаубицы-пушки МЛ-20 (позже использовалась в самоходке ИСУ-152), разработка 122-миллиметровой самоходки повышенной мощности М-22 [7, ф. 889. оп. 1, д. 413, л. 17-19], 76-миллиметровой дивизионной пушки БЛ-14, 85-миллиметровой 
противотанковой пушки БЛ-19 [8, с. 57] и других. Главным конструктором ОКБ-172 был М.Ю. Цирульников, который за разработку важнейших для страны артиллерийских систем по ходатайству наркома вооружения Д.Ф. Устинова в 1943 г. был досрочно освобожден. Многие другие конструкторы остались в заключении.

В послевоенное время деятельность и существование этих подневольных научно-исследовательских бюро была засекречена, а эта часть биографии бывших заключенных умалчивалась, как часто и их имена. Так, в протоколе V Общезаводской партконференции пушечного завода №172 от 11-12/V-46 г. про ОКБ 172 говорится: «Завод имел два конструкторских бюро. К.Б., возглавляемое т. Ивановым, дало в начале машины М-42 и ОБ-26, которые были приняты на вооружение. К.Б., возглавляемое т. Гуренко, дало совместно с Челябинским, самоходную установку» [7, ф. 889, о. 2, д. 1, л. 69-70]. Товарищ Иванов Николай Алексеевич - подполковник государственной безопасности (ГБ), а с 1943 г. - полковник ГБ - возглавлял ОКБ со стороны НКВД. Необходимо отметить, что Н.А. Иванов кроме званий госбезопасности имел инженернотехническое образование - в 1933 г. окончил военное отделение Ленинградского электротехнического института и в 1936 г. - военную академию РККА им. Буденного по специальности «военный электротехник». До службы в НКВД и ГБ успел поработать старшим инженером нескольких московских заводов [9, с. 225]. Сергей Петрович Гуренко - главный конструктор заводского КБ в годы Великой Отечественной войны. То есть даже в архивных документах, на то время строго секретных, второе конструкторское бюро, состоящее из заключенных, упоминается вскользь - только имя начальника КБ по линии НКВД.

В 1976 г. был открыт музей Мотовилихинских заводов в подведомственном ДК им. Ленина. Сохранились буклеты этого музея - 1988 и 1991 гг. В буклете 1988 г. в разделе «Ратный подвиг Мотовилихи» перечисляются наименования пушек, разработанных и выпускавшихся в годы Великой Отечественной войны, в том числе М-42, МЛ-20. Фамилии конструкторов и условия создания этих пушек не указаны [10, с. 7]. В буклете 1991 г. перечислены не только пушки, но имеются сведения о главном конструкторе С.П. Гуренко и других конструкторах гражданского КБ [11, с. 20-22]. Таким образом, пушки, сконструированные ОКБ-172 НКВД, ока- 
зались приписаны заводскому КБ. В 1987 г. музей переехал в историческое здание недалеко от проходных, и в связи с этим была перестроена экспозиция, в которой в то время ничего не говорилось о «шарашке» и заключенных. В 1990 г. перед музеем появилась площадка с пушками под открытым небом [12, с. 83]. У каждого экспоната (пушки) была сделана табличка, в которой были написаны и имена конструкторов - Петров, Гуренко. Тем не менее в основной экспозиции были представлены два альбома середины 1960-х гг., в которых без раскрытия истории и особенностей работы ОКБ, состоявшего из заключенных, приводятся под фотографиями изделий названия конструкторских бюро, в том числе ОКБ-172, и имелись редкие фото конструкторского бюро 1946 г. На фото в центре стоит М.Ю. Цирульников - тогда уже главный конструктор пушечного завода, еще недавно бывший заключенным ОКБ-172. Внимательный посетитель музея мог при желании, листая альбомы, увидеть, что на заводе было два КБ во время Великой Отечественной войны (рис. 1).
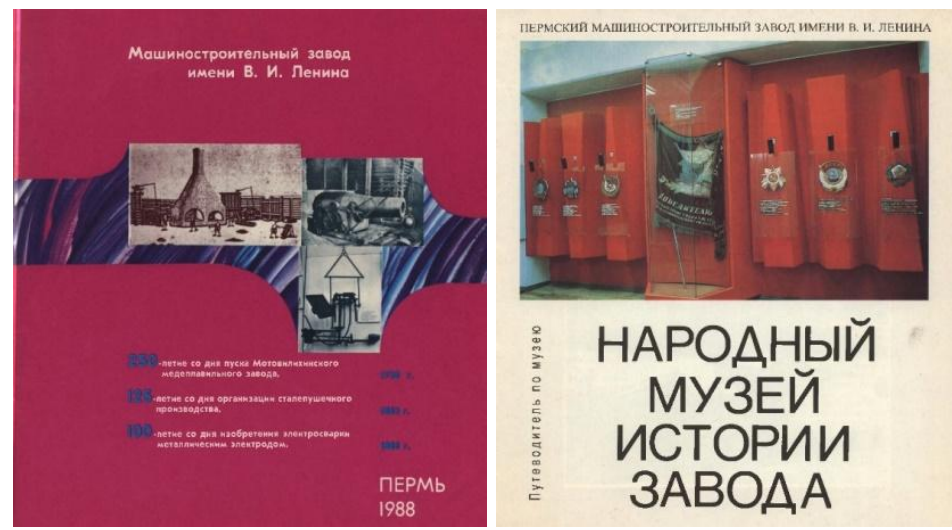

Рис. 1. Буклеты музея Мотовилихинского завода

В начале двухтысячных годов появился и музей порохового завода в подведомственном ДК им. Кирова. Время уже позволяло, и в экспозиции были стенды, посвященные заключенным ученымхимикам - Д.И. Гальперину, А.Э. Спориусу, Б.И. Пашкову, В.А. Лясоцкому, Ф.М. Хритинину. 
Важным шагом в изучении и сохранении памяти о лагерных конструкторских и технических бюро стала инициатива Самарского филиала российского Государственного архива научнотехнической документации (РГАНТД). В 2006 г. РГАНТД начал масштабный научно-исследовательских проект «Во имя справедливости: архивы рассказывают». Данный проект ставил своей целью поиск и сбор материалов о репрессированных в советское время деятелях науки и техники, изобретателях, внесших определенный вклад в развитие инженерной мысли. В проект включился и Государственный общественно-политический архив Пермской области (сейчас - ПермГАСПИ). При сборе материала большую помощь оказали сотрудники музеев Порохового завода и Мотовилихинских пушечных заводов. В ноябре 2007 г. в Самаре был проведен круглый стол по теме «Историко-архивное восстановление имен и достижений Отечества». К этому круглому столу была создана на основе собранного архивного и музейного материала выставка «Во имя справедливости: архивы рассказывают». В создании выставки приняли участие сотрудники московских, казанских, нижегородских, екатеринбургских и пермских архивов. На выставке были представлены уникальные документы, рассказывающие о судьбе и творчестве таких известных людей, как С.П. Королев, В.П. Глушко, В.В. Парин, П.Ф. Флоренский, и многих других (рис. 2). Эти люди, незаслуженно обвиненные во «вредительстве», «троцкизме», «антисоветской деятельности», своими исследованиями и открытиями способствовали развитию страны. Пермяки представили пять стендов. Стенд «Геологи, нужные стране», рассказывал о судьбах открывателя прикамской нефти П.И. Преображенского и расстрелянного пермскими чекистами геолога Н.Н. Приемских, специально посланного в 1918 г. на Урал для поиска полезных ископаемых. Три стенда были посвящены массовым репрессиям 1937-1938 гг., задевшим в том числе пермских инженеров-конструкторов. На последнем стенде были представлены пермские «шарашки» - ГУЛАГовские конструкторские бюро. На этом стенде, вероятно, впервые были представлены две известные нам «шарашки» и несколько судеб заключенных, в том числе - М.Ю. Цирульникова и Д.И. Гальперина. К сожалению, выставка, проработав несколько месяцев в Самаре, в Пермь так и не приехала. По итогам выставки был издан научный альманах «Те- 
лескоп. Историко-архивное восстановление имен и достижений Отечества», в котором была размещена статья «Репрессии в отношении научно-технической интеллигенции в Прикамье (19181950-е годы)» [13, с. 157-164].
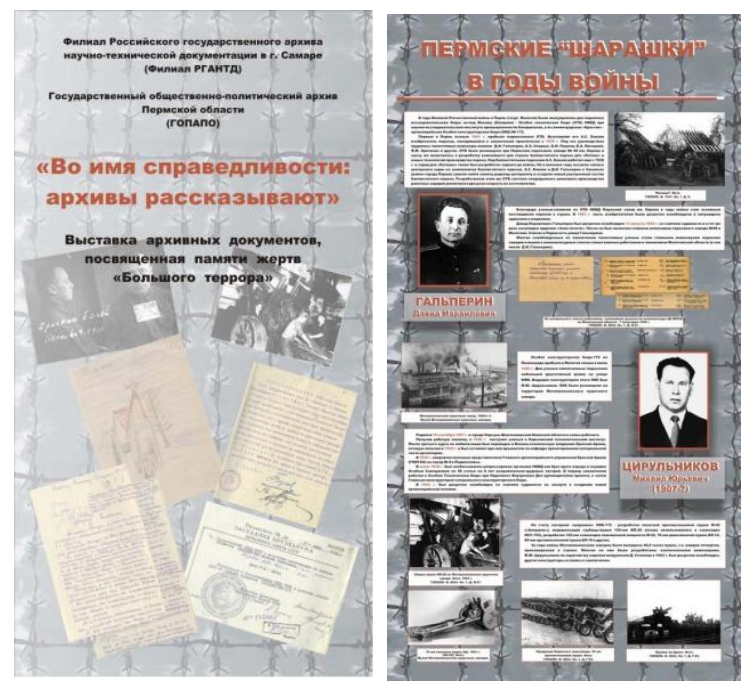

Рис. 2. Стенды выставки в Самаре

Следующий шаг в сохранении памяти о «шарашках» сделал пермский «Мемориал». В октябре 2010 г. в здании бывшей Пересыльной тюрьмы, тюрьмы НКВД №2, Промколонии №1 был открыт просветительский центр «История тюрьмы НКВД №2» [14]. Через эту тюрьму или позже - промколонию - прошли тысячи человек, среди которых было немало осужденных по 58-й статье. Именно в стены Промколонии №1 в 1942 г. прибыла эвакуированная из Ленинграда сначала в Томск, а потом в Молотов (Пермь) «спецтюрьма» ОКБ-172. В Промколонии №1 заключенные ОКБ были разделены на две большие группы - часть конструкторов, специализировавшихся на морской артиллерии, отправили в г. Молотовск (современный Северодвинск), тех, кто занимался сухопутной артиллерией, перевели «на одну из боковых тихоньких улочек... в Мотовилихинском районе» [15, с. 64]. В просветительском центре был стенд, посвященный этой «шарашке» и заключенным в ней. К сожалению, через несколько лет плодотворной работы, просветительский центр был закрыт. 
Сотрудники Мемориального музея-заповедника истории политических репрессий «Пермь-36» давно планировали музеефицировать память о заключенных «шарашек». В 2020 г. решено было создать сразу две выставки о «шарашках» - виртуальную и реальную. Виртуальная выставка позволяет рассказать вообще обо всех подобных учреждениях и о людях, бывших в них. После работы по сбору материалов была сделана на специальном сайте https://sharashka.su/ выставка «Мужество науки. Конструкторское бюро особого режима. Истории о тех, чьи знания и труд стали вкладом в Победу» (рис. 3). Основными разделами стали «Репрессии против ученых», «Ученые в лагерях», «Первые шарашки», «Персоналии». Раздел «Репрессии против ученых» рассказывает о «спецеедстве» 1920-х гг., высылке из страны людей науки и заключении в лагеря. В разделе «Персоналии» приводится судьба более 20 ученых, исследователей, конструкторов, репрессированных по политическим статьям и работавшим в лагерных конструкторских бюро. Отдельные блоки посвящены пермским «шарашкам» и судьбам заключенных этих учреждений - М.Ю. Цирульникова, А.С. Бакаева и другим. Особенностью интернет-выставки является то, что ее можно постоянно пополнять, добавлять новые материалы, новые судьбы, воспоминания о том времени. Так, летом 2020 г. на выставку были добавлены расшифрованные воспоминания сына Михаила Юрьевича Цирульникова - Игоря Михайловича - об отце и о том непростом времени [16]. Эти воспоминания были записаны в 2016 г. пермским журналистом Вячеславом Дегтярниковым и переданы им в мемориальный музей-заповедник «Пермь-36». Виртуальную выставку за 2020 г. посетило 4025 человек.

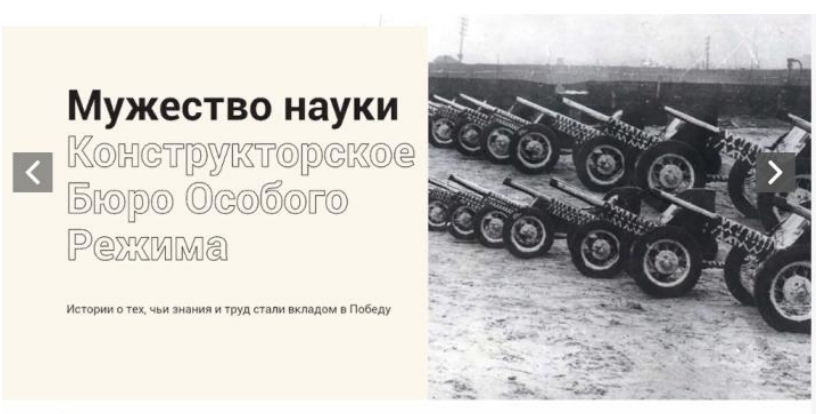

Рис. 3. Первая страница сайта https://sharashka.su/ 


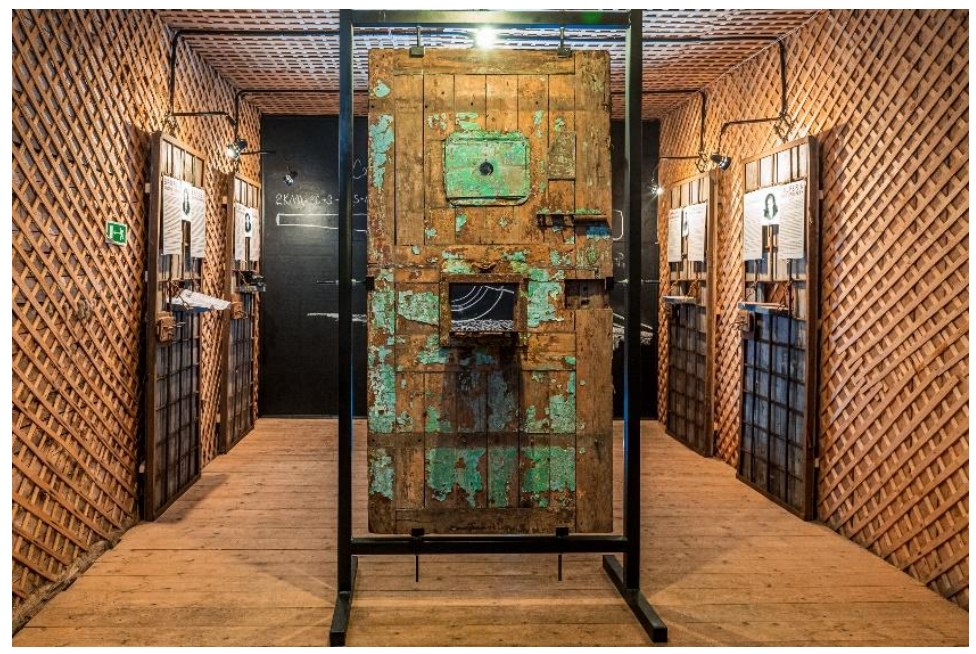

Рис. 4. Выставка в музее-заповеднике «Пермь-36» «Мужество науки»

В августе 2020 г. уже на территории музея-заповедника была открыта выставка «Мужество науки» (рис. 4). Выставка разместилась на территории бывшей промышленной зоны участка строгого режима. Одним из важных экспонатов выставки стала настоящая тюремная дверь Томской пересыльной тюрьмы. Особое конструкторское бюро из Ленинграда первоначально планировалось эвакуировать в Казань. Вероятно, предполагалось слияние с Зеленодольским ОТБ. 21 июля 1941 г. этап заключенных был отправлен в Казань, но благодаря военной неразберихе оказался в Томске [8, с. 50]. И только в июле 1942 г. инженеры-конструкторы прибыли в Молотов. В ПермГАСПИ сохранился протокол заседания бюро Сталинского районного комитета партии г. Молотова (современный Свердловский район г. Перми), на котором рассматривался вопрос о возможности создания партячейки при спецтюрьме, прибывшей из Томска [17, ф. 231, оп. 1, д. 123, л. 28]. Таким образом, инженеры этого ОКБ почти год провели в тюрьме Томска. Тюремная дверь также символизирует разделение жизни ученых на дотюремную и тюремную со следственными камерами, допросами, избиениями, невероятными и совершенно незаслуженными обвинениями. В этой выставке показаны четыре судьбы - инженеров 
М.Ю. Цирульникова и С.И. Лодкина, химиков - Д.И. Гальперина и А.С. Бакаева. Инженеры были в ОКБ №172 в Мотовилихе, а химики в ОТБ № 98 в Закамске. Предметный ряд выставки крайне беден - это объясняется секретностью оборонной деятельности ученых. Тем не менее был найден арифмометр, который применялся в КБ Мотовилихинского завода примерно в то же время, когда там была «шарашка», книги, использовавшиеся пермскими конструкторами, сын Цирульникова передал в музей-заповедник уникальные фотографии. Все это позволило создать две локации - тюремную камеру и рабочее место ученого в конструкторском или техническом бюро при НКВД СССР. Выставку с момента ее открытия, несмотря на условия пандемии, посетили более 2700 человек.

Ученые и изобретатели, осужденные за «вредительство», названные «врагами народа», добросовестно и плодотворно трудились в тюремных конструкторских бюро. В тюремных КБ, находившихся в Перми (тогда Молотове), были созданы мощнейшие образцы военной техники, разработаны новые технологии производства пороха и новые составы порохов. В отчете Четвертого спецотдела НКВД СССР за 1939-1944 гг. приведены десятки изобретений - самолеты, моторы, пушки, подводные лодки, катера, радиостанции, прибор ночного боя [3, с. 445-450]. Особо были отмечены в отчете достижения пермских исследовательских бюро. Деятельность ученых в лагерных «шарашках» приближала Победу, и их вклад не должен быть забыт.

\section{Список литературы и источников}

1. Николаев А.С. Большевистская власть и «спецы»: «Ни малейшей политической уступки этим господам»! // Толерантность и власть: судьбы Российской интеллигенции. - Пермь, 2002. - 350 с.

2. Крук Н.С. История ОКБ-172 // Вестник «Мемориала». 2001. - № 6. -279 с.

3. История сталинского ГУЛАГа. Т.3. Экономика ГУЛАГа. М.: РОССПЭН, 2004. -624 с.

4. Нуриев Р.Т. Особые конструкторские и технические бюро («шарашки») г. Казани в 1940-х гг. По мемуарам и свидетельствам современников [Электронный ресурс] // РСМ. 2018. №4 (101). URL: https://cyberleninka.ru/article/n/osobye-konstruktorskie-i- 
tehnicheskie-byuro-sharashki-g-kazani-v-1940-h-gg-po-memuaram-isvidetelstvam-sovremennikov (дата обращения: 29.10.2020).

5. Д.И. Гальперин. Ученый. Учитель. Патриот. - Пермь, 2003. $-92 \mathrm{c}$.

6. Плюснина O.М., Степанов М.Н. Военно-промышленный комплекс Западного Урала // Бессмертный подвиг народа. Пермь, 2000. - 166 с.

7. Пермский государственный архив социальнополитической истории (ПермГАСПИ).

8. Крук Н.С. Орудия победы // «Вестник Мемориала». 2001. - № 6. -279 с.

9. Кто руководил НКВД. 1934-1941: справочник. - М.: Звенья, 1999. - 502 с.

10. Машиностроительный завод им. В.И. Ленина. - Пермь, 1988.

11. Пермский машиностроительный завод им. В.И. Ленина. Народный музей истории завода: путеводитель по музею. - Пермь, 1991.

12. Зенкова Н.А. История музея завода // Мотовилиха: открывая новые страницы: тезисы докладов научно-практической конференции. - Пермь, 2011. - 180 с.

13. Шевырин С.А. Репрессии в отношении научнотехнической интеллигенции в Прикамье (1918-1950-е годы) // Телескоп: научный альманах. Специальный выпуск. Историкоархивное восстановление имен и достижений Отечества. - Самара: Научно-технический центр, 2008. - 192 с.

14. Просветительский центр «История тюрьмы НКВД №2» [Электронный ресурс]. - URL: // http://pmem.ru/1071.html // (дата обращения: 29.11.2020).

15. Воспоминания Фомченко С.И. Материалы к истории ОКБ-172. // Вестник «Мемориала». - 2001. - №6. - 279 с.

16. Воспоминания Цирульникова И.М. [Электронный реcypc]. - URL: https://Sharashka.Su/Vospominaniya-SynaVospominaniya-Syna-Czirulnikova/ (дата обращения: 29.10.2020). 